\title{
Evaluating the Impact of GST on the Growth of Manufacturers, Distributors, Retailers, Freelancers, Startups Etcetera Differently in the IT sector -An Empirical Research
}

\author{
Arun Gautam, Gaurav Lodha, M L Vadera
}

\begin{abstract}
The implementation of Goods and Services Tax has impacted various services differently. In case of the IT sector, it has eradicated the cascading taxes and abided by the policy "One Tax One Nation”. It has made things clearer for online software selling companies as it distinctly talks about products and services. It incurs fewer costs to service providers. Cost of input machinery has dropped. However, now the companies have to register in all the states it wants to operate in and pay CGST. This also means that filing returns and accounting becomes difficult to manage due to decentralization registration. Although there wasn't much benefit in terms of the cost but there were some other benefits that are discussed in the paper.

Index Terms-GST - Goods and Services Tax, IT sector Information Technology Sector,ERP - Enterprise Resource Planning.
\end{abstract}

\section{INTRODUCTION}

The implementation Goods and Servicoes Tax (GST) has been the igniting spark for the growth of economy in India by changing the already prevalent ways of indirect taxation towards the unrestricted flow of various goods and services which, without a doubt was very much needed. It has eradicated the cascading effect of taxes making the cumulative figure a huge one, which the Indian public was giving. Goods and Services Tax, better known as GST is an indirect tax which aims to make our Country a common and unified market. It is applied on the supply of goods and services within country. The taxes collected by the Centre till July 1st, 2017 include Excise duty (medicinal and toilet preparations), Central Excise duty, Additional Duties of Excise (on textile and its products), extra Duties(goods of special importance), Customs duties, Service Tax, and Central surcharges. The State taxes consist of State VAT, Entry Tax, CST, EAT (movies and entertainment), LT, PT, Taxes on activities such as advertising, gambling, and State surcharges , betting, lotteries etc[1]

\section{RESEARCH PROBLEM}

In economic crisis across the earth, our country has given hope with ambitious growth aims, supported by strategic undertakings such as the Make in India and Digital India campaigns. The Goods and Services Tax (GST) is another such undertaking that has provided the much needed

Revised Manuscript Received on April 12, 2019.

Mr. Arun Gautam, Department. of Commerce, Manipal University Jaipur, India.

Dr. Gaurav Lodha, Prof. Department of Commerce, Manipal University Jaipur, India.

Prof. (Dr.) M L Vadera, Department of Commerce, Manipal University Jaipur, India. stimulant for economic growth in India. This paper aims to highlight the impacts of GST on the Information Technology Sector of India and how it affects the growth of the Indian economy.

\section{RESEARCH OBJECTIVE}

To study the how GST helped in the growth of manufacturers, distributors, retailers, freelancers, startups etcetera differently in the IT sector.

\section{RESEARCH METHODOLOGY}

Being a Descriptive Research Study- Analytical Research Design, it is based on secondary data of Journals, Articles, Newspapers and Magazines. Considering the objectives of study descriptive type research design is adopted to have more accuracy and rigorous analysis of the study.

\section{IMPACT OF GST ON THE IT SECTOR:}

I. Change in taxable component and simplification in payment method from multiple points to single point

Goods and Services Tax (GST) is the reason for the onset of 'one nation one tax' policy that our country has abides by. It can be observed that it's effect on different sectors of the economy producing section varies immensely. The first layer of differences that can be spotted in the industry deals with distributors, manufacturers and retailers or service providers.

* Impact of GST on Distributors, Manufacturers and Retailers

Introduction of many indirect taxes increased the money invested in the administration by manufacturers and distributors. But with GST in being in order, the burden has slightly eased t allowing the sector to grow more strongly. However, due to the application of the same, businesses which weren't yet under the tax radar now have to come out and register. This has been a huge factor in cutting down the amount of tax evasion that takes place in India.[2]

\section{* Impact of GST on Service sector}

The crazy amount of number of operatives under the 'Information Technology' sector fall in the category of tertiary industry, that of 'Service Providers'. The major IT giants (including Indian arms of Multinational companies

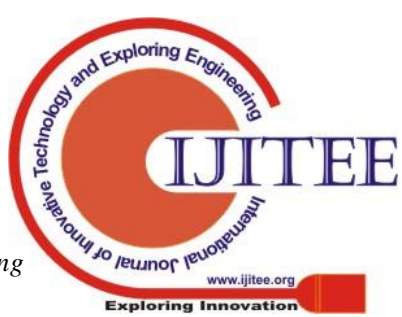


and pure Indian industries); the medium to small scaled start-ups and the various freelancing units, all fall in this category.

\begin{tabular}{|c|c|c|c|}
\hline Particulars & GST & $\begin{array}{l}\text { Service tax (including SBC } \\
\text { and KKC) }\end{array}$ & Difference \\
\hline $\begin{array}{l}\text { ABC Itd. provides } \\
\text { services to X for an } \\
\text { amount of Rs } \\
50,00,000 \text {. }\end{array}$ & $\begin{array}{l}18 \% \text { of the } \\
\text { taxable } \\
\text { services. Tax } \\
\text { liability = Rs } \\
9,00,000(A)\end{array}$ & $\begin{array}{l}\text { 15\% of the taxable } \\
\text { services. Tax liability = Rs } \\
7,50,000(B) \text {. }\end{array}$ & $\begin{array}{l}\text { Additional } \\
\text { tax of Rs } \\
1,50,000 \text { (C) } \\
\text { under GST }\end{array}$ \\
\hline $\begin{array}{l}\text { ABC Itd. also paid tax } \\
\text { on goods of Rs } \\
5,00,000 \text { purchased for } \\
\text { providing above }\end{array}$ & $\begin{array}{l}\text { service. Input tax } \\
\text { credit = Rs } \\
90,000 \text {. }\end{array}$ & $\begin{array}{l}\text { Input tax credit Rs } \\
75,000-(0.5 \% \text { * Rs } \\
5,00,000 \text { SBC) }=\text { Rs } \\
72,500 .\end{array}$ & $\begin{array}{l}\text { SBC is not } \\
\text { allowed as } \\
\text { credit.Additi } \\
\text { onal ITC } \\
\text { benefit } \\
\text { under GST= } \\
\text { Rs } \\
17,500(D) .\end{array}$ \\
\hline
\end{tabular}

* IT Service Providers

In the service sector, the IT service, the Insurance industry, telecommunication service, business support services, banking service and financial service etc. have the max tax burden. As most of these businesses are pan-Indian, which are already working in a market that is unified, it is very much expected to see the burden decrease. But they definitely will have to register in each state individually and abide by the CGST laws of each.

\section{* Start-ups}

A considerable share of IT sector in India today comprises the 'start-up or incubator industry. With the limits for registration lifted higher, a Do It Yourself model of compliance, tax credit on purchases and an unrestricted flow of various goods and services, the GST regime truly suited for Indian startups. Earlier, multiple states had different laws for VAT which led to immense confusion for companies which had a pan-India presence, particularly the ecommerce sector as it spans the whole nation. But GST has brought an end to all such practices.

\section{* Freelancers}

Freelancing in India is an untouched industry/sector, \& the regulations and rules for this chaosful industry are still up in the air and are not made or not clear. But with Goods and Services Tax, it would become much easy for them to file/ pay their taxes because now they can do it online. They are treated as service providers, and taxed accordingly and the new tax structure has also brought about order and accountability/responsibility in this sector. [3]

* Tax Rates under Excise/VAT/Service Tax
Previously, the production and sale of software attracted VAT rate of about $5 \%$ in most states and service tax rate of about $15 \%$. Excise duty was also there for manufacturing.

* Tax Rates under GST

All such complications and double taxation is removed under GST.

However, the taxable component may not see much change (as can be seen from the figures). The only advantage, then, remains the decrease in multiple tax points to a single or at most two points (State and National GST) II. The expected boom in the IT industry to cater to the increased requirement of customised softwares and ERP packages by the wide range of Industries.

\section{* Businesses}

All businesses, small and large are running to get their ERPs and accounting systems in accordance with GST. It means a blast in costs of infrastructure and changes/ alterations in business systems. Big companies have set up teams consisting of their own experts in technical field, financial experts, and experts from their GST software client. Hence, this demand for GST software vendors is increasing and will blast in recent years. [4]

* Redesigning business software IT service providers

- The redesigning business software IT service providers, can now pay their taxes (input) against the service provided. For example, now they can adjust VAT paid on office supplies against the service provided by them.

- Also IT companies maintaining servers, used to incur huge capital expenditure on buying the hardware and also revenue expenditure on repair and maintenance. Now the tax paid on hardware can be adjusted against the tax paid on services and small parts of repairs, thus reducing the overall tax burden

- The biggest hurdle is in changing the IT systems which require coordination between tax experts and technology teams. In many cases, some of the ERP software that were provided by the IT majors have to be redesigned and updated with the new GST rules.[5]

- ERP (Enterprise Resource Planning) is business process management software that makes the process of integrating applications to manage the business and automate many back office functions related to technology, services and human resources easy for the organizations. It includes integrating product planning, development, manufacturing sales and marketing all in a single application. Therefore, it is also known as enterprise application.

* Companies are mainly upgrading their enterprise resource planning (ERP) and accounting software to accommodate the complexities of calculating GST. Either they need to upgrade their existing software to the new version or use specific GST software like the Cleartax GST.[6]

\& 
- Software Developers and Sellers

- There is a race for companies to develop a GST software. GST will impact these companies positively by opening a huge market pan India. Demand for GST sotfware by all the companies will mean a huge boost to these sottware developers.

Cleartax is the first company in India with a live ready-to-use GST sotware. Many more such enterprises will spring up now.

\section{* Export of Services}

- Export of information technology is one of the most important source of foreign exchange, with India being the biggest exporter of IT services.

- Exports are zero-rated and input taxes paid will be allowed as a refund. The typical IT/ ITES services come under the default rule are software development, BPO operations, sottware consultancy, etc.

- Apart from these, the rule applies to other services like sottware support maintenance and intermediary services as there are no exceptions

\section{FINDINGS \& RESULTS}

After the Goods and Services Tax (GST) was implemented in our Country, India, a major change could be seen in the prices of products and services offered by the IT Sector. It is important to study GST effect in this sector because it comprises a huge part of the GDP. It is no secret that GST implementation has simplified the tax system in India by eliminating the many indirect taxes and establishing the single GST , thereby removing the cascading of various taxes.

\begin{tabular}{|l|l|l|l|l|l|}
\hline $\begin{array}{l}\text { Manufactur } \\
\text { er }\end{array}$ & $\begin{array}{l}\text { tax } \\
\text { type }\end{array}$ & Rate & $\begin{array}{l}\text { Amoun } \\
\mathrm{t}\end{array}$ & Tax & $\begin{array}{l}\text { Credit } \\
\text { Availme } \\
\mathrm{nt}\end{array}$ \\
\hline $\begin{array}{l}\text { On } \\
\text { manufactur } \\
\text { er }\end{array}$ & $\begin{array}{l}\text { Exer } \\
\text { cise }\end{array}$ & $12.50 \%$ & 10000 & 1250 & $\begin{array}{l}\text { CVD, } \\
\text { ST, ED } \\
\text { credit }\end{array}$ \\
\hline On sale & CST & $2.00 \%$ & 11250 & 225 & $\begin{array}{l}\text { Cannot } \\
\text { claim } \\
\text { credit }\end{array}$ \\
\hline Total & & $14.50 \%$ & & 1475 & \\
\hline
\end{tabular}

- Manufacture of Computer Hardware After GST

\begin{tabular}{|l|l|l|l|l|l|}
\hline $\begin{array}{l}\text { Manufact } \\
\text { urer }\end{array}$ & $\begin{array}{l}\text { tax } \\
\text { type }\end{array}$ & Rate & $\begin{array}{l}\text { Amo } \\
\text { unt }\end{array}$ & $\begin{array}{l}\text { Ta } \\
\mathrm{x}\end{array}$ & $\begin{array}{l}\text { Credit } \\
\text { Availment }\end{array}$ \\
\hline $\begin{array}{l}\text { On } \\
\text { manufactu } \\
\text { rer }\end{array}$ & $\begin{array}{l}\text { CGS } \\
\mathrm{T}\end{array}$ & $\begin{array}{l}9.00 \\
\%\end{array}$ & $\begin{array}{l}1000 \\
0\end{array}$ & $\begin{array}{l}90 \\
0\end{array}$ & $\begin{array}{l}\text { CGST and IGST } \\
\text { credit }\end{array}$ \\
\hline On sale & IGST & 9.00 & 1000 & 90 & CGST,SGST \\
\hline
\end{tabular}

\begin{tabular}{|l|l|l|l|l|l|}
\hline & & $\%$ & 0 & 0 & and IGST credit \\
\hline Total & & $\begin{array}{l}18.00 \\
\%\end{array}$ & & 18 & \\
& & 00 & \\
\hline
\end{tabular}

SERVICES: The services provided by the software industry however, are now charged at $18 \%$ when before GST implementation, it was only $15 \%$.The IT companies had to make the hardware and software products in order to bring their systems in congruence with the GST law. This in turn, resulted in the spiking of infrastructure cost, thus affecting the capability of the business.[7]

- Export of Computer Software

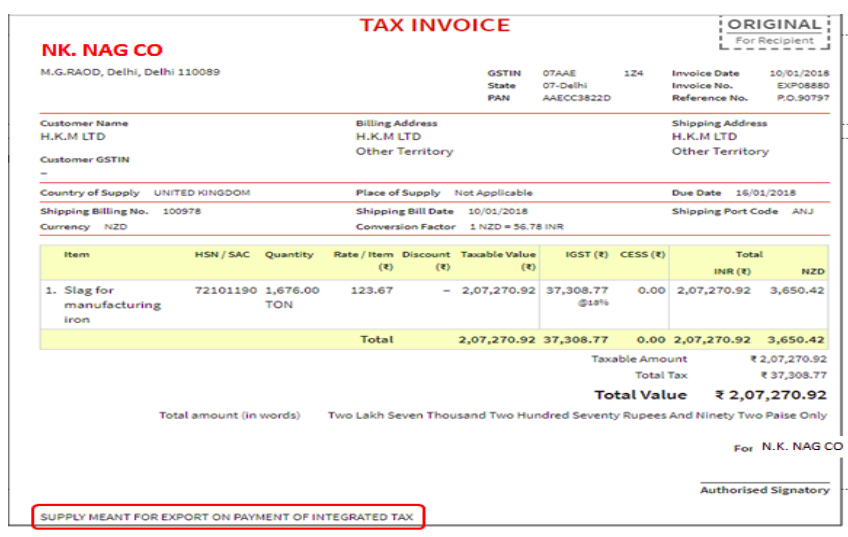

Here we see, the tax applied on total amount of export is Rs. $37,308.77$ which $18 \%$ GST tax on the amount Rs. 2, $07,270.92[8]$

- Renting of IT Cloud Services (Amazon Web Services)

\begin{tabular}{|c|c|}
\hline \multicolumn{2}{|l|}{ Summary } \\
\hline AWS Service Charges & $\$ 0.59$ \\
\hline Charges & $\$ 0.50$ \\
\hline Credits & $\$ 0.00$ \\
\hline GST & $\$ 0.09$ \\
\hline Total for this statement in USD & $\$ 0.59$ \\
\hline Total for this statement $(1 \text { USD }=71.125000 \text { INR })^{1}$ & INR 41.96 \\
\hline
\end{tabular}

Here, we see that the tax on renting a cloud service is $18 \%$.

- Sale of Computer Hardware before and after GST

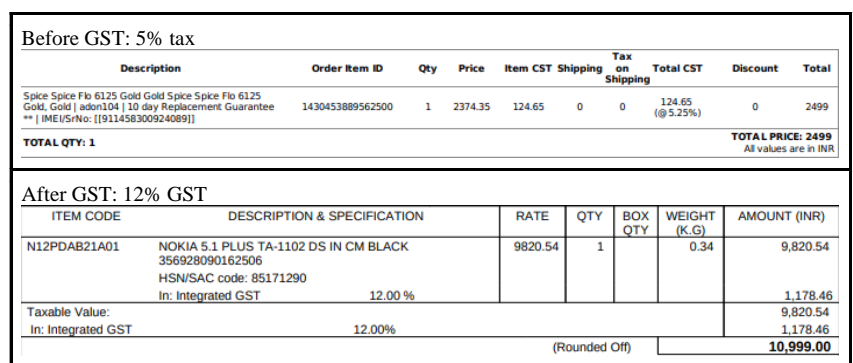

- Sale of Computer Hardware:

- RAM

- Lightning cable 


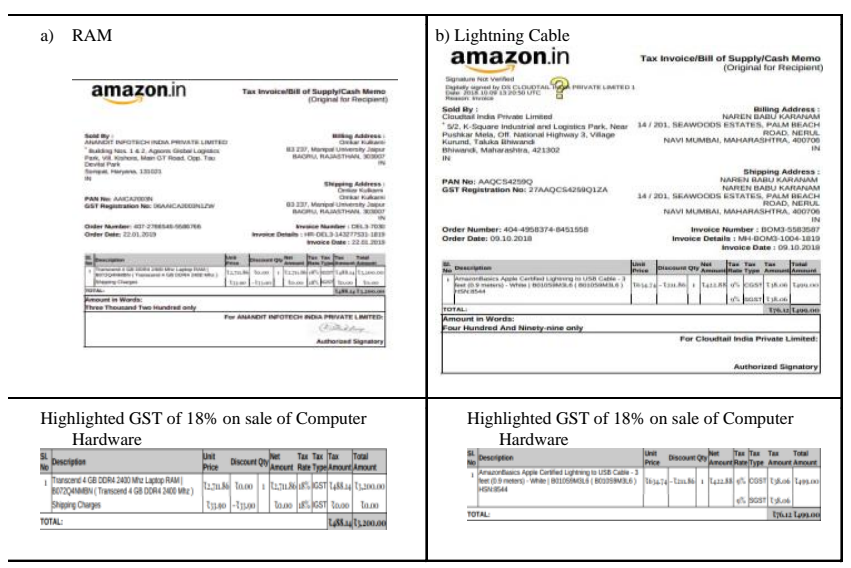

According to GST, a variety of products employed in this sector, for example, Printer, fax and xerox machines, cartridges used in the aforementioned and such, attract GST at the rate of $28 \%$. However, earlier, the tax rate was only as high as $18 \%$.[9]

\begin{tabular}{|l|l|}
\hline PRODUCT NAME & GST rate \\
\hline Mobile Phone & $12 \%$ \\
\hline Chargers & $28 \%$ \\
\hline Earphones & $18 \%$ \\
\hline Batteries & $28 \%$ \\
\hline Power Bank & $28 \%$ \\
\hline Memory Card & $18 \%$ \\
\hline USB Cable & $28 \%$ \\
\hline Speakers & $18 \%$ \\
\hline Headphones & $18 \%$ \\
\hline
\end{tabular}

Apart from mobile phones the table above shows the GST rates for other hardware and software products.

\section{CONCLUSION}

Recapitulating the findings in our paper, we see

- Taxation on manufacture of computer hardware before GST was $5 \%$ and $14.5 \%$, while after GST it is $12 \%$ and $18 \%$ respectively.

- Export of computer software, after GST has $18 \%$ taxation applied on it.

- Renting of IT Cloud services also has an $18 \%$ of GST.

Even though the GST rate for services has increased to $12 \%$ and $18 \%$, IT industry/sector would definitely benefit from GST. It is because of the immense boost in the sale of the software. Also there are other factors like availability of ITC (Input Tax Credit), they would bring down other costs (eg - operating cost) and thus, it would contribute in growth of the overall profitability of the this sector. Though there's no significant change in the amount of cost price invested in the inputs and other manufacturing units, the It sector has still benefited from the GST regime because of simplicity of the taxation system. The service providers and freelancers in this sector have clearly benefited. Companies on the other hand, have an advantage due to the existence of ERPs.

\section{REFERENCES}

1. Gupta, U. Impact of GST on Indian Retail. Recent Trends \& Practices in Managemen, 133.

2. Goel, S. (2017). Evaluating the impact of gender sensitivity training on public officers' attitudes-an empirical study. International Journal of Indian Culture and Business Management, 14(2), 198-213.

3. KANDA, R., Handa, H., \& Bhalla, G. S. (2018). MPACT OF GST ON THE WORKING OF RURAL INDIA-A Study Assessing the Impacts of the New Indirect Taxation System on the Unorganised Business Sector in Lower Himachal Pradesh. IOJPH-International open Journal of Business \& Management Science, 1(2), 21-28.

4. Kaur, J. (2016). Goods and service tax (GST) and its impact. International Journal of Applied Research, 2(8), 385387.

5. Lodha, S., Kumawat, E., \& Bapna, C. Impact of Demonetization Announcement on Indian Stock Market: An Event Study. I congratulate the editorial team and advisory board for bringing IX edition of this journal with their continued efforts. I wish you all the best in your all such academic pursuits. 4.

6. Lourdunathan, F., \& Xavier, P. (2017). A study on implementation of goods and services tax (GST) in India: Prospectus and challenges. International Journal of Applied Research, 3(1), 626-629.

7. Malar, G. J. B. The Effect of GST on Indian E-commerce Industry.

8. Mukherjee, S., \& Rao, R. K. (2015). Policy options for including petroleum, natural gas and electricity in the Goods and Services Tax. Economic and Political Weekly, 50(9), 98107.

9. Nath, B. (2017). Goods and services tax: A milestone in Indian economy. International Journal of Applied Research, 3(3), 699-70

\section{AUTHORS PROFILE}

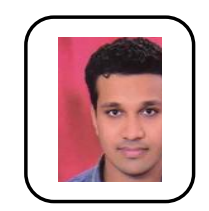

Arun Gautam, Research Scholar, Dept. of Commerce, Manipal University Jaipur



Dr. Gaurav Lodha, Corresponding Author Associate Professor Manipal University Jaipur

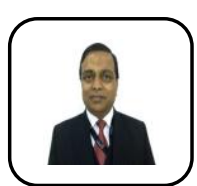

Prof. (Dr.) M.L. Vadera

Director, School of Business \& Commerce Manipal University Jaipur. 